\title{
Female Principals in Education: Breaking the Glass Ceiling in Spain ${ }^{1}$
}

\author{
Enrique Javier Diez Gutierrez ${ }^{2}$ \\ Universidad de León, León, Spain
}

\begin{abstract}
Spanish schools are characterised by having a high proportion of female staff. However, statistics show that a proportionately higher number of men hold leadership positions. The aim of this study was to analyse the reasons why this is so, and to determine the motivations and barriers that women encounter in attaining and exercising these positions of greater responsibility and power. Questionnaires were administered to 2,022 female teachers, 430 female principals and 322 male principals. In addition, semi-structured interviews were held with 60 female principals, 14 focus group discussions were held with female principals and 16 autobiographical narratives were compiled with female principals and school inspectors. The reasons identified were related to structural aspects linked to the patriarchal worldview that is still dominant in our society and culture. Nevertheless, we also found motivations among women for attaining and exercising leadership roles.
\end{abstract}

Keywords: social equality, women, management, leadership, discrimination

\section{Diretoras em Educação: Quebrando o Teto de Vidro na Espanha}

\begin{abstract}
Resumo: As organizações escolares espanholas são caraterizadas pela grande proporção de mulheres que nelas trabalham. Porém, os dados estatísticos demonstram que, proporcionalmente, o número de homens em cargos de direção é superior. O objetivo deste estudo foi o de analisar as razões que explicam este fenômeno: as motivações e barreiras que as mulheres encontram para ascender e exercer estes cargos de maior responsabilidade e poder através da aplicação de questionários a 2.022 professores, 430 diretores e 322 conselheiros, além da realização de entrevistas com 60 diretores, coordenação de 14 grupos de discussões com diretores e condução de 16 entrevistas autobiográficas com diretores e inspetores de ensino. Os motivos identificados relacionam-se com factores estruturais associados a cosmovisões patriarcais, ainda dominantes na nossa sociedade e cultura. Porém, também foi possível verificar motivações entre as mulheres para ascenderem ao exercício destes cargos diretivos.
\end{abstract}

Palavras-chave: igualdade social, mulheres, direção, liderança, discriminação

\section{Directoras en Educación: Rompiendo el Techo de Cristal en España}

\begin{abstract}
Resumen: Las organizaciones escolares españolas se caracterizan por el alto índice de mujeres que trabajan en ellas. Sin embargo, los datos estadísticos demuestran que el número de hombres es superior en proporción en puestos de dirección. El estudio de las razones por las cuales ocurre esto es el principal objetivo de este artículo: las motivaciones y obstáculos que encuentran las mujeres para acceder a estos cargos de mayor responsabilidad y poder y ejercerlos, mediante la aplicación de cuestionarios a 2.022 profesoras, 430 directoras y 322 directores, así como 60 entrevistas semiestructuradas a directoras, 14 grupos de discusión con directoras y 16 autobiografías de directoras e inspectoras de educación. Las causas identificadas tienen que ver con aspectos estructurales, ligados a una cosmovisión patriarcal aún dominante en nuestra sociedad y cultura. Pero también se han hallado motivaciones para el acceso y desempeño del cargo directivo para las mujeres.
\end{abstract}

Palabras clave: igualdad social, mujeres, dirección, liderazgo, discriminación

The number of women in school leadership positions in Spain is much smaller than would correspond to them if they were represented in proportion to the number of women working in this field. Furthermore, there is a much larger

\footnotetext{
${ }^{1}$ Support: This article draws on the research project Gender culture in educational organisations, which received $€ 25,125$ in funding from the Spanish Ministry of Health, Social Services and Equality under the National Plan for Scientific Research, Development and Technological Innovation (BOE 24/04/02) and on the research project Women's access to leadership positions in educational organisations, which received $€ 26,600$ in funding from the Regional Government of Castile and León (Spain) within the Research Project Support Programme (Order 14/03/02).

${ }^{2}$ Correspondence address:

Enrique Javier Diez Gutierrez. Facultad de Educación, despacho 146. Campus de Vegazana. Universidad de León. 24071 León, Spain. E-mail: enrique.diez@unileon.es
}

number of women at the bottom of the pyramid, in pre-school and primary education and in small schools considered less influential or prestigious due to their size.

According to official data for 2013 published by the Spanish Ministry of Education, Culture and Sport, women account for more than two thirds (70.2\%) of teachers working in the nonuniversity general education system. This percentage rises to $78.5 \%$ among teachers in pre-school and primary education, although it drops to a more balanced level for teachers in secondary education (57.8\%). Moreover, this disproportionate representation has increased over the last decade.

The late 1990s witnessed the first school leadership studies in Spain to introduce the gender perspective, an approach that attracted increasing research interest in subsequent years (Coronel Llamas, Carrasco Macías, \& Moreno Sánchez, 2012; Gómez Delgado \& Moreno 
Sánchez, 2011; Moncayo Orjuela \& Pinzón López, 2013; Moncayo Orjuela \& Villalba Gómez, 2014; Tomás Folch \& Guillamón Ramos, 2009; Wallace \& Marchant, 2009; White \& Özkanli, 2010; etc.). All these studies have reported a very low percentage of female representation in school leadership positions at all educational levels.

Coronel Llamas et al. (2012) found that $61.3 \%$ of leadership positions in pre-school and primary education were occupied by men, compared with the $38.6 \%$ occupied by women. Traditional explanations of this unequal occupation of school leadership positions have typically drawn on arguments based on psychology and individual traits (Montero Alcaide, 2010), whereby women's scant entry into leadership positions is attributed to their personal difficulties or handicaps. Such arguments have included women's socalled "fear of success" (García, 2006), the precedence they give to "life priorities" over professional demands, and the difficulties entailed in a post and the consequent psychological stress involved, coupled with women's desire for an easy life, with the result that "women avoid making life difficult for themselves" (Cáceres Reche, Trujillo Torres, Hinojo Lucena, Aznar Díaz \& García Carmona, 2012). These explanations in fact represent an attempt to blame the barriers on the women themselves, turning the victims into the culprits, since in essence they assert that the women do not want these roles.

However, the causes and reasons uncovered in the present Spanish study indicate that low female representation in school leadership positions is more related to structural aspects of our society and culture that stem from the dominant patriarchal worldview transmitted from generation to generation, which is so ingrained that it is difficult to change.

Since the 1980s, various studies have employed the term glass ceiling to describe this phenomenon (Coronel Llamas et al., 2012; Eliseo Valle, 2012; Gómez Delgado \& Moreno Sánchez, 2011; Tomás Folch \& Guillamón Ramos, 2009; White \& Özkanli, 2010), using the metaphor of an invisible glass barrier to refer to all those intangible obstacles that block the progress of many women in the labour market and give rise to the vertical discrimination evidenced by the decreasing proportion of women the further up one moves in any organisational pyramid. Other authors have referred to this phenomenon as the sticky floor, since it seems that the floor at the bottom of the pyramid glues women so firmly into place that they are unable to break free and enter higher level positions.

The aim of the research reported here, conducted in Spain, was to explore the positive reasons that have led women to assume leadership positions in school organisations, and the limits or difficulties they have encountered in attaining and exercising these roles.

\section{Method}

Although the methodology employed was fundamentally qualitative, it was also characterised by negotiation between quantitative and qualitative methods, an approach which has been called triangulation. The complexity of education would seem to lend itself to the complementary use of both methods. Triangulation enhances both methodologies, yielding perspectives and perceptions that neither of the two approaches could provide on their own. Furthermore, it enables data and information to be contrasted. When opinions and data are compared and contrasted, new information emerges that had remained hidden in previous explorations. It was for this reason that the various instruments employed to collect information were triangulated in order to obtain different perspectives and enable a comparison of the data obtained.

\section{Participants}

The study sample was obtained from all over Spain, encompassing public pre-school, primary and secondary education centres and considering population and geographic distribution (urban, semi-urban and rural). A mean number of 12 schools per province throughout the country were invited to participate, with the aim of including at least 3 female teachers and the female or male principal from each school in the study. A total of 2,774 teaching staff participated in this research, of whom 2,022 were female teachers, 430 were female principals and 322 were male principals.

\section{Instruments}

For the quantitative aspect of the study, we designed two ad hoc questionnaires which were then administered to 2,022 female teachers and 752 female and male principals. The two questionnaires explored three themes: barriers to access; reasons for access and positive aspects found in the performance of their duties; and desirable behaviours and attitudes in the exercise of leadership. One was administered to female teachers and contained 25 questions, while the other was administered to female and male principals and contained 28 questions. Both questionnaires consisted of five sections: (a) presentation (explaining the purpose of the research); (b) personal data; (c) reasons why they would not choose to be a principal, in the case of female teachers, or obstacles to attaining this post in the case of female and male principals; (d) reasons that would lead them to consider applying for leadership positions, in the case of female teachers, and positive aspects that they have found in the exercise of the post in the case of female and male principals; and (e) desirable attitudes and behaviours in the exercise of leadership.

For the qualitative aspect of the study, we designed a guide for conducting the semi-structured interview with female principals, which was divided into four blocks or sections of questions. The first section concerned questions about their expectations of the exercise of leadership, the second focused on issues related to their personal experience of leadership, the third on the leadership tasks they had to perform, and lastly, the fourth regarded their assessment of women's participation in management teams. Since the questions were open-ended and the interview instructions were intended for guidance only, the interviews were flexible and could be adapted to the responses, interests and direction indicated by the female principal during the interview.

In addition and again from the perspective of qualitative methodology, we conducted 58 field observations in Spanish 
schools throughout the country, accompanying female principals as they performed their duties, and held 14 focus group discussions with female and male principals and female teachers. We also conducted 60 interviews with female principals and female school inspectors with wide-ranging responsibilities, and collected 16 autobiographical narratives.

Compilation of the autobiographical narratives, also framed within the qualitative methodology, involved collecting the female principals' subjective accounts over the course of successive interviews, with the intention of reflecting both events and the subjects' assessments of their own experiences of leadership. The aim was not only to record the events experienced by female principals, but also to document their responses to these events, seeking their explanations and the meaning they attributed to these.

This procedure enabled us to triangulate qualitative and quantitative instruments in such a way as to render these methodological approaches mutually complementary and to enrich and complement the data obtained.

\section{Procedure}

Data collection. Six research stages were designed, the first of which was to conduct a review of the literature. The second stage was descriptive, and entailed observing the significant events and interactions that occurred in school leadership dynamics, analysing the behaviour of female principals compared to that of their male colleagues.

To this end, the research team visited 36 pre-school centres and primary schools and 22 secondary schools to conduct field observations over a period of not less than seven days over the course of one month, on non-consecutive days. For a previously agreed period of time, female principals were systematically accompanied to the activities scheduled in their diaries, such as staff meetings, management team meetings and appointments with families or the education authorities, in order to observe acts of management and leadership.

The most relevant aspects identified in the first stage were explored further in the third stage, which was of an intensively descriptive nature and was based on conducting 60 interviews and compiling 16 autobiographical narratives with female principals and school inspectors with wideranging responsibilities and considerable experience in their positions. Although not recorded, informal meetings held with the interviewees also provided a wealth of information.

In the fourth stage, which consisted of an extensive and representative survey, the data obtained in the previous stage were employed to design two ad hoc questionnaires. These were then administered to a large sample of the study population of female teachers and principals in order to confirm the provisional results identified in the third stage. The questionnaire aimed at female teachers was answered by 2,022 teachers, and the questionnaire aimed at principals was answered by 752 teachers, of whom 430 were female principals $(57.18 \%)$ and 322 were male principals (42.82\%). The fifth, comparative stage consisted of holding 14 focus group discussions with between six and ten participants, in which female and male principals and female teachers discussed and contrasted the findings obtained in the previous stages during open, non-directed debate. Lastly, the sixth and final stage entailed triangulation of the results obtained with these different instruments.

Data analysis. The quantitative data obtained from the questionnaire were analysed using the statistical software package SPSS, which yielded the values for descriptive and inferential statistics, as well as evidence of validity and reliability. Both questionnaires were found to be highly reliable and consistent, obtaining a Cronbach's alpha of .887 and a validity of $79.45 \%$. Meanwhile, a content analysis was conducted of the open-ended interview questions and the focus group responses, identifying categories by means of multiple descriptive and interpretive coding performed with the AQUAD computer program for combined processing and analysis of all information.

The data obtained from the research instruments were processed and analysed according to the following categories: cultural reasons for this imbalance (related to social custom, pressure to conform or the persistence of the maternal myth in education); social expectations and the bad mother syndrome; achieving a work-life balance; the male definition of power (understood as the sole universal male subject, based on the definition of power as conquest); expectations; invisible male networks (the stereotype of think-leadership-think-men, the selection mechanisms for access to management, life priorities); rituals of exclusion; the lack of female role models; invisibility and lack of awareness of discrimination; and the question of internal barriers (women's so-called fear of success, selfexpectations and self-esteem in the exercise of leadership).

\section{Ethical Considerations}

All ethical considerations were observed throughout the research. Informed consent was sought from the institutions where data were collected, as was that of each study participant. The confidentiality of all data was ensured. Below, we present the research results and discuss the findings.

\section{Results}

The external barriers hindering women's access to leadership positions included those inherent to the existing social structure (e.g. co-optation, achieving a work-life balance, and the perpetuation of typically masculine values in positions of power in so far as these are still largely exercised by men) and those related to beliefs about leadership and gender (e.g. beliefs about a lack of ambition, leadership qualities or interest in exercising power, the attribution of biological sex to professions or the high levels of performance demanded of women).

An ad hoc classification was formulated for the present study in which obstacles were divided into contextual barriers (related to the dominant patriarchal social culture in which all are socialised and which all have assimilated prior to entering school) and organisational barriers (related to school structure and organisation, also shaped by the dominant patriarchal worldview). Notable contextual barriers 
included the socialisation process through which strong social pressure is exerted to conform; fear of failing to comply with the traditional maternal and care-giving role attributed to women and difficulties in achieving a work-life balance. Organisational barriers included the low levels of motivation aroused by the prevailing traditional leadership style, social expectations about the exercise of power in schools, invisible networks through which implicit systems of co-optation are established, lack of role models in leadership positions and the invisibility of discrimination.

\section{Socialisation and Social Pressure to Conform}

The first cause we detected was related to the historical, social and cultural tradition in which women particularly have been socialised, namely, the pressure to conform to social custom. This social pressure, which represents an implicit and powerful standard, inclines all members of society to conform so as not to stand out, and to meet social expectations. These results are in agreement with those reported in other recent studies in this field (Cáceres Reche et al., 2012; Isaac, BeharHorenstein \& Koro-Ljungberg, 2009; Moncayo Orjuela \& Villalba Gómez, 2014; Murillo Torrecilla \& Román Carrasco, 2013). Social custom has traditionally prompted women to assume roles related to the domestic and private sphere.

Furthermore, our research revealed implicit social support for men to assume positions of responsibility, a circumstance which was celebrated and valued by their family and friends. In the case of women, on the other hand, undertaking a leadership role was perceived as an additional problem and correlated directly with the assumption that this would necessarily imply neglecting other responsibilities, which were usually related to the private sphere and included, for example, emotional neglect of the woman's partner, less time for child care and neglect of household chores.

My family thought it was awful. No, I mean it, awful. They were all "don't do it", all the time. I think it was also to do with what I was going through at that particular point in my life, I had just spent three years of brutal work on the saga of textbooks, and they saw the time it had taken me and said now, just when we were hoping you'd be finished with this, you go and..., but I think that was just at the beginning, after that I received support like always, anything that I set myself to do... I think it's a process of getting used to an idea... and then they end up saying, well, if she says she's going to do something, she does! (LET)

Women thus experienced less emotional and practical support when assuming such roles, as well as encountering an attitude of discouragement, if not outright opposition. It is not that women shy away from leadership positions, it is that men shy away from family responsibilities.

\section{The Expectations of the Traditional Role of Motherhood and Care}

On a social level, it would seem that a fairly widespread criticism, or at least an implicit pressure, persists towards women who give precedence to professional success over the predominant role historically and socially assigned to them: a perception linked to motherhood. It is considered acceptable for a man to devote less attention to his family if he holds a position of responsibility, but when a woman does the same she is accused of neglecting her family. In the professional world, marriage and children are seen as positive attributes in men, as factors that ensure stability, whereas a woman who has or might have children is seen as a potential burden in terms of maternity leave, available working hours and priorities when making decisions.

My female principal colleague resigned because she had young children and her post involved various activities outside school hours, spending time in meetings, there was a very good atmosphere and we wanted to continue like that: carrying out projects, innovation projects, new methodologies. My personal situation had something to do with it, it helps that I'm not married, and I can devote all the time I deem appropriate. (AE)

In women, this tends to generate negative psychological consequences, as described by the female participants themselves in the present study, provoking distress and anxiety about the "alleged neglect" in terms of the care and education of their children that is entailed in the assumption of a leadership position. Furthermore, the woman's own fears in this respect are exacerbated by those in her social and emotional environment, who tend to consider her a "bad mother", reinforcing her feelings of anxiety.

\section{The Difficulty of Achieving a Work-Life Balance}

Whereas increasing numbers of women are entering the public sphere, very few men are entering the private sphere and devoting equal amounts of time and dedication attending to domestic tasks and family life.

Some $91.6 \%$ of the men (almost all of them) considered that women's greatest barrier to access was their family responsibilities. It is significant in this regard that $60 \%$ of the female principals in office disagreed with this conclusion, shared almost unanimously among men.

We found that by the time women who accepted leadership positions acceded to their post, they had made the necessary arrangements that would enable them to balance the multiple roles of education professional, homemaker and family care-giver. This undeniably involved personal and professional strain. As several studies in this field have indicated, men's use of time is independent of marital status or having children (Callejo Gallego, Gómez Esteban, \& Casado Aparicio, 2004; López Yáñez \& Sánchez Moreno, 2009; Moncayo Orjuela \& Pinzón López, 2013; Murillo Torrecilla \& Román Carrasco, 2013; Powell, Butterfield, \& Parent, 2002). For women, however, the transition from being single to marriage involves a loss of nearly three hours of time devoted to professional and academic work, while the time they devote to domestic and family activities increases by almost 4 hours. For men, marrying or living together as a 
couple is much like finding a maid, whereas for women, it is like taking on a second job. Thus the myth of the superwoman is born; the woman who gets everything done and does everything well. This engenders a reactive rejection towards anything that makes life more difficult, and even more so in the case of assuming leadership positions, since women know that they will have to take care of everything.

\section{Low Levels of Motivation Aroused by the Prevailing Style of Traditional Leadership}

A third reason was related to the way in which the times and structures of school leadership positions were usually organised, since these were generally designed for individuals who enjoyed a full-time support system at home. A key feature of management positions as they are currently organised from an essentially masculine perspective - is an increase in the length of the working day. Devoting more hours to a leadership position appears essential to achieve recognition in this role.

Moreover, the criteria used to measure competence and the requirements for occupying leadership positions were linked to traits traditionally attributed to men: control, hierarchical authority, respect and obedience to one's superior, determination, self-confidence, competitiveness and social success. "I have to assume that some men are much more willing to accept men rather than women in leadership positions" (LJP). "When we talk about being ambitious or being competitive, these are considered positive traits in a man but defect in a woman" (LAA).

These characteristics are alien to organisational cultures influenced mainly by women, in which more emphasis is placed on interpersonal relationships and power sharing, with a more collaborative leadership style that is open and democratic and entails mutual consensus, teamwork and shared responsibilities and work, promoting the development of communities based on collective values and actions. Such organisations reflect the belief that management is best when it is collective, that leadership is most productive when it is shared, and that the main function of management is to create a good work atmosphere.

Therefore, it seems that one of the key explanations for the absence of women in leadership roles was their lack of identification with the prevailing model of leadership, and the differences between the methods, manners and styles of female principals and those of their male colleagues.

Similarly, we found that men and women narrated their professional trajectories differently: whereas the former tended to depict their careers in individual terms, the latter tended to present them as part of other, more collective projects. For the men, leadership appeared to be a means to attain power, social prestige and recognition. In contrast, the reasons the women gave for assuming leadership positions were essentially related to a clear intention to bring about change in their schools. They tended to view it as a service to the educational community and as a personal contribution to the attempt to improve the organisation.

The attitude of the male principals was associated with an emphasis on professional achievement. In addition, it appeared that it was mainly men who presented themselves as candidates for the post of principal in schools and they also showed more interest in assuming this position. In the majority of cases, when a woman presented her candidature for the post of principal, there was no other candidate; in contrast, in $81.49 \%$ of cases when men presented their candidature, there were other candidates or opponents.

\section{Social Expectations Regarding the Exercise of Power}

Society has better expectations of how men will exercise leadership compared with women, who are expected to do worse than men because it is thought that men are more used to exercising power and are traditionally trained to do so. The three advantages of men cited in this study were: "male principals have more credibility in the eyes of teaching staff and students"; "they command more respect and even fear in direct confrontation with men, and therefore teaching staff are more compliant"; and "in the eyes of students, and even sometimes of teaching staff, they are thought to be more capable of imposing order". Participants also stated that "there is more faith in men's decision-making ability", that "women are thought to be insecure and afraid of assuming responsibility" and "there is more acceptance of an order or a correction if it comes from a male principal".

The notion still persists that men know how to deal with problem better. There is still the idea that what a man says about a problem carries more weight, and any solution is better received if it is proposed by a man. (LET)

However, not only is there a presumption that men are worthier than women, but also higher demands are made of women: women are required to prove and demonstrate in practice their ability to command respect. Based on the belief that because of their sex, women may be unable to rise to the challenge, they are almost required to be exceptional.

Sometimes, interviewees reported that an ambition to succeed or an attempt to comply with the prototypical profile of a leader put pressure on women to adopt a masculine style, as has been shown in other studies. Surprisingly, however, women who do adopt an authoritarian style are considered more negatively than men who do so; they are branded as iron women, and there is a tendency to consider them as being more aggressive, manipulative and dominant.

\section{The Invisible Networks of Co-Optation}

Another of the factors influencing the scarcity of female principals in schools was the existence of what have been termed invisible networks or invisible associations, terms that refer to the subtle, implicit and in many cases unconscious strategies that men deploy to support other men as they move up the hierarchy of power. Such rituals are necessary to enter the world of authority so effectively governed, understood and managed by men. "I know that all the inspectors in this province are men, and they are the ones who propose the principals. I know that some things lead to others, if fewer women present themselves for leadership positions, then when it comes to proposing them..." (LCG). "when people 
think about who would be good as principal, they tend to think of a man" (CE).

These interwoven networks reinforce expectations of suitability regarding men's capacity, in turn generating selection mechanisms designed for and favourable to men, thus enhancing the informal support and mentoring afforded men who aspire to become principals, and conversely, discouraging - obviously informally - any women to do so or reminding them of the risks and difficulties that such a course of action might entail.

As experts in the field have indicated, the phrase "think manager, think male" has become a commonplace (Coronel Llamas et al, 2012;. Isaac et al., 2009). Male principals think of men for posts of responsibility, male school inspectors think of men for leadership positions and male teachers think of men to occupy these leadership positions. They have all established mechanisms of trust based on very similar expectations, common goals and similar ways of thinking that have been forged in informal meetings over lunch, dinner, drinks and coffees together.

When the time came to elect a new principal, we would get together over a working lunch and talk a little about who it might be... I realise that, well, there were always more men than women at these lunches, it's true, but even so, there were always far more men's names than women's being proposed for the post. And then the other posts, well... they could always be a secretary or such like. And it's very funny because if a woman suggested the name of another woman, it would come as a surprise, and these were people who would never in their lives think of themselves as chauvinists, and what's more, they might not be. (LJR)

\section{Lack of Role Models in Leadership Positions}

Another reason was the lack of role models with which women could identify of women in leadership positions who exercised their power differently to men in the same position. "In my school, always. Except when I was on the management team, when we accounted for $50 \%$, there have always been fewer women, never at the top of the pyramid and always in a proportion of $50 \%$ or less" (at the end of the interview, LCG).

However, in contrast to this lack of a role model for the post of female principal, there were female role models for the post of secretary, which is performed in a discreet and less visible manner than that of the principal or head of studies. It seems that the position of secretary, traditionally performed by women and with a markedly auxiliary nature with respect to other positions of power occupied by men, persists in schools as a reflection of business practices.

This lack of role models is also reflected in the traditional use of language. In fact, the Spanish language itself denies the possibility of identification since there are no equivalent female terms for the title of some positions. Similarly, theoretical treatises on management and leadership are generally written in the generic masculine.

\section{The Invisibility of Discrimination}

However, perhaps the most invisible factor in the field of education was the firm conviction among much of the educational community that discrimination no longer exists. Despite the persistent existence of statistical and quantitative data on the prevalence of men over women in senior positions in the educational world, the majority of people surveyed and interviewed did not clearly perceive this to be the case. The majority of participants consistently and clearly stated that in the light of their own personal experience, "discrimination doesn't exist anymore".

The logical conclusion therefore, is that if something is not working, it must be due to women's inadequacy. Thus, it is no longer simply the case that women do not aspire to leadership positions, but that furthermore they are unsuitable for them. This inverted interpretation constitutes victim blaming: it is the women themselves who do not want to be or are incapable of being principals. Discrimination is attributed to internal factors, to people's individual characteristics.

Many of the respondents felt that it was a problem of personality or experience, whereas others sought causal attributions and claimed that women "have no ambition". Gender barriers were transformed into obstacles related to the abilities or inabilities, wishes or interests of individual women.

Thus, as explained in the autobiographical narratives, women who showed a greater awareness of gender discrimination and explicitly voiced this, risked rejection or ridicule. This situation leads us to conclude that inequality and gender discrimination is the most covert of all injustices, because it is perceived as normal, and what is normal is not questioned.

Mention should also be made of the motivations and positive aspects reported by the women who participated in this research as regards attainment or performance of leadership positions. According to the female principals: (a) assuming a leadership position provided an "opportunity to improve the school", and facilitated their personal and professional development; (b) their families and children "became more independent" as a result of the mother being at home less; (c) their children expressed "greater respect for the professional work" their mothers performed as principals, although they initially perceived this as a loss of attention; (d) they provided their children with a "model of equal education in practice", demonstrating that the public sphere was not just the sole preserve of men but could also be occupied by women; (e) they became a "role model for equality in the school" for male and female students alike, breaking the stereotype that leaders are necessarily men; (f) they lost their "fear of power", as they saw that they were able to perform the tasks involved in the exercise of the principal's role not only skilfully and effectively, but also better than many men; $(\mathrm{g})$ the role of principal as a complex position requiring skills quite unlike those traditionally attributed to women was demystified; (h) they "developed fundamental skills" associated with the exercise of a leadership role (public speaking, planning, human resource management, social representation, etc.) that women have fewer opportunities to practice because they do not often 
attain this level; (i) their "self-concept and self-esteem was enhanced", because the exercise of this role endowed most of the women who participated in this study with the perception that the educational community held an extremely positive opinion of their work as principals; $(j)$ they gained a "a gender perspective in the exercise of leadership" in their analysis, interpretation and response to many of the situations that arose (for example, encouraging female students to become representatives on the school council or to assume positions of responsibility). This facilitated the education of young women by giving them opportunities for participation and real decision-making, and created a "support network" for the entry of other women into leadership positions.

\section{Discussion}

First, it should be noted that perceptions of the existence of barriers were not homogeneous. This divergence was partly related to the individual nature of each participant's personal experience but also to the tacit means by which many of these barriers operate as well as to the gender identity the participants constructed over the course of their biographical and professional trajectories (Tomás Folch \& Guillamón Ramos, 2009).

The barriers that women encounter to attaining leadership positions are related to the predominance of a network of male meanings which is embodied in a series of rules and structures that favour a male model of professional development and attainment of educational leadership (Bernal Agudo, 2014; Ruiz Corbella, 2013). Gender stereotypes in terms of effective leadership are directly harmful to women, since they only relate good leadership to qualities that are considered masculine. The problem is that the gender stereotypes currently prevalent in today's society are often internalised by women themselves, as many studies have demonstrated (Barrios-Arós, Camarero-Figuerola, TiernoGarcía, \& Iranzo-García, 2015; Bernal Agudo, 2014; López Yáñez \& Sánchez Moreno, 2009; Villa Sánchez, 2015).

In general, most studies (Callejo Gallego et al., 2004; Coronel Llamas et al., 2012) have shown that the concept of leadership has been constructed on the basis of a hierarchical and individualistic approach, particularly at secondary education level. However, current research on leadership (Barrios-Arós et al., 2015; Coronel Llamas et al., 2012; Lerche Vieira \& Maia Vidal, 2015; Moncayo Orjuela \& Villalba Gómez, 2014; Ruiz Corbella, 2013) suggests the need to eradicate these practices from our organisations in favour of shared leadership models.

As Coronel Llamas et al. (2012) and Moncayo Orjuela and Villalba Gómez (2014) have proposed, more studies are required that document the experiences of women in leadership positions in order to confirm and give greater substance to the evidence and results obtained, and these should encompass not only access to the post of principal, but also its abandonment and succession.

From the outset, the entirety of human history has been profoundly shaped by patriarchy. The current situation is one in which distorted images of women not only persist but also continue to perpetuate established roles which emphasise women's responsibility in the home rather than in professional life.

Thus, having women in leadership positions forms one of the essential conditions for the practice of equality within schools. This is especially important because what future generations of men and women learn at school does not just consist of what they are explicitly taught, but also of what they see and experience as regards the organisation and operation of these institutions in which they spend an important and crucial part of their lives.

In contrast, what perhaps stands out most clearly is that the decision of the women who participated in this study to assume a leadership position was strongly motivated by a commitment to improving the school in which they worked as teachers, as well as a concern for all students and for the teaching and learning process. Those aspects related to salary, status or social recognition played a very secondary role. Lastly, it is worth noting that all the women who had had experience of a leadership position expressed satisfaction over their performance in the post and stated that exercising the role had reinforced their self-esteem.

\section{References}

Barrios-Arós, C., Camarero-Figuerola, M., Tierno-García, J. M., \& Iranzo-García, P. (2015). Modelos y funciones de dirección escolar en España: El caso de Tarragona [Models and functions of school management in Spain: The case of Tarragona]. Revista Iberoamericana de Educación, 67, 89-106.

Bernal Agudo, J. L. (2014). Funciones de los directores escolares: Una nueva función pública hacia el gerencialismo [Functions of school principals: A new civil service towards managerialism]. Forum Aragón, 12, 18-26.

Cáceres Reche, M. P., Trujillo Torres, J. M., Hinojo Lucena, F. J., Aznar Díaz, I., \& García Carmona, M. (2012). Tendencias actuales de género y el liderazgo de la dirección en los diferentes niveles educativos [Present trends of gender and the leadership management in different educational levels]. Educar, 48(1), 69-89. doi: $10.5565 /$ rev/educar.36

Callejo Gallego, J., Gómez Esteban, C., \& Casado Aparicio, E. (2004). El techo de cristal en el sistema educativo español [The glass ceiling in the Spanish educational system]. Madrid, España: Universidad Nacional de Educación a Distancia.

Coronel Llamas, J. M., Carrasco Macías, M. J., \& Moreno Sánchez, E. (2012). Superando obstáculos y dificultades: Un estudio multicaso sobre directoras escolares, políticas de liderazgo y gestión para la mejora [Overcoming obstacles and problems: A multicase study of women principals, leadership policies and management for school improvement]. Revista de Educación, 357, 47-61. doi:10.4438/1988-592X-RE-2011-357-072

Eliseo Valle, J. (2012). La dirección de centros docentes de 
educación primaria en clave de género [The management of schools of primary education in key gender]. TS Nova: Trabajo Social y Servicios Sociales, 6, 35-46.

García, T. (2006). Los porqués de la ausencia de las maestras en la dirección escolar [The whys of the absence of the teachers at the school office]. Andalucia Educativa, 55, 7-10.

Gómez Delgado, A. M., \& Moreno Sánchez, E. (2011). Una brecha en el poder de las organizaciones educativas: Las directoras de los centros escolares andaluces [A gap in the power of educational organizations: The directors of the Andalusian schools]. Clepsydra: Revista de Estudios de Género y Teoría Feminista, 10, 77-98.

Isaac, C.A., Behar-Horenstein, L. S., \& Koro-Ljungberg, M. (2009). Women deans: Leadership becoming. International Journal of Leadership in Education, 12(2), 135-153. doi:10.1080/13603120802485102

Lerche Vieira, S., \& Maia Vidal, E. (2015). Gestão democrática da escola no Brasil: Desafios à implementação de um novo modelo [Democratic management of schools in Brazil: Challenges for the implementation of a new model]. Revista Iberoamericana de Educación, 67, 19-38.

López Yáñez, J., \& Sánchez Moreno, M. (2009). Mujeres agentes de cambio en la dirección de organizaciones universitarias [Women as change agents in the headship of higher education organizations]. Revista de Educación, 348, 331-353.

Moncayo Orjuela, B., \& Pinzón López, N. P. (2013). Mujeres líderes en la academia, estereotipos y género [Women leaders in academia, gender and stereotypes]. Panorama, 7(13), 75-94. doi:10.15765/pnrm.v7i13.433

Moncayo Orjuela, B., \& Villalba Gómez, C. E. (2014). Obstáculos de la mujer en el acceso a cargos de dirección y liderazgo: Incidencia de los planteles educativos [Obstacles women face for accessing management and leadership positions: Impact on educational institutions]. Panorama, 8(15), 59-79. doi:10.15765/pnrm.v8i15.550

Montero Alcaide, A. (2010). Dirección profesional y selección de directores en el sistema educativo español [Professional school headship and selection processes in the Spanish educational system]. Revista Española de Pedagogía, 68(247), 417-435.

Murillo Torrecilla, F. J., \& Román Carrasco, M. (2013). La distribución del tiempo de los directores de escuelas de educación primaria en América Latina y su incidencia en el desempeño de los estudiantes [How Latin-American primary school principals distribute their time and the effect on student performance]. Revista de Educación, 361, 141-170. doi:10.4438/1988-592X-RE-2011-361-138

Powell, G. N., Butterfield, D. A., \& Parent, J. D. (2002). Gender and managerial stereotypes: Have the times changed? Journal of Management, 28(2), 177-193. doi:10.1016/S0149-2063(01)00136-2

Tomás Folch, M., \& Guillamón Ramos, C. (2009). Las barreras y obstáculos para el acceso de las profesoras universitarias a los cargos de gestión académica [Barriers to the access of women to management positions at University]. Revista de Educación, 350, 253-275.
Ruiz Corbella, M. (2013). Liderazgo y responsabilidad educativa: El necesario liderazgo de directores y profesores de la educación [Leadership and educational responsability: The necessary leadership of principal and teacher in education]. Fuentes: Revista de la Facultad de Ciencias de la Educación, 14, 85-104.

Villa Sánchez, A. (2015). El liderazgo pedagógico como factor clave para la renovación educativa en los centros escolares [Pedagogical leadership as a key factor for educational renewal in schools]. Padres y Maestros, 361, 5.

Wallace, M., \& Marchant, T. (2009). Developing female middlemanagers in Australian universities. High Education, 58(6), 781-797. doi:10.1007/s10734-009-9225-x

White, K., \& Özkanli, O. (2010). A comparative study of perceptions of gender and leadership in Australian and Turkish universities. Journal of Higher Education Policy and Management, 33(1), 3-16. doi:10.1080/136008 0X.2011.536976

Enrique Javier Diez Gutierrez is a Professor of the Facultad de Educación at Universidad de León.

Received: Aug. 13, 2015

1st Revision: Dec. 8, 2015

Approved: Dec. 9, 2015

How to cite this article:

Diez Gutierrez, E. J. (2016). Female principals in education: Breaking the glass ceiling in Spain. Paidéia (Ribeirão Preto), 26(65), 343-350. doi:10.1590/198243272665201611 